\title{
A Critical Comprehension of Carbon Neutral Management Practices in Agriculture by Tribal Farmers of Betul District of M.P, India
}

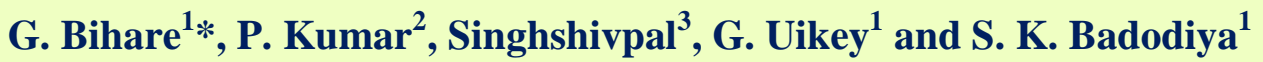 \\ ${ }^{1}$ Department of Agriculture Extension Education, College of Agriculture, \\ Gwalior-474002, India \\ ${ }^{2}$ Department of Agriculture Extension Education, College of Agriculture, \\ Indore-452001, India \\ ${ }^{3}$ Department of Agriculture Extension Education, Jawaharlal Nehru Krishi Krishi Vishwa \\ Vidyalaya Jabalpur M.P, 482007, India \\ *Corresponding author
}

A B S T R A C T

Keywords

Eco-Friendly

Practices, Tribal

Farmers, ill effect,

Agrochemical

Article Info

Accepted:

15 April 2020

Available Online:

10 May 2020
The present study was conducted in Sahapur and Bhimpur block were purposively selected based on tribal area of Betul district of M.P. The total sample was consisted 120 respondents for the study. Objective of study is to study the profile of tribal farmers, and to seek suggestive measure to minimize the ill effect of agrochemical as perceived by tribal farmers. maximum respondents were from middle age group having maximum respondents educated up to primary level, having medium size of family, most of the respondents had medium social participation, having marginal size of land holding, having medium annual income, maximum respondent were in medium category regarding credit availability, having medium source of information category, approximately half of the respondents were in medium category regarding material possession, having medium category of extension contact also extension participation, as well as medium category regarding innovativeness.

\section{Introduction}

In today's word, Agriculture and technology are the backbone of an economy. While agriculture makes significant contribution to the economic development of less developed countries. Environmentally friendly agriculture production is the process in which crops are grown naturally without the use of chemicals. The main purpose of this activity is to produce agriculture without harming the environment. This kind of farming is a production process which avoids or largely excludes using synthetically compounded 
fertilizers, plant hormones and dairy cattle feed additives. a feed additive is an additive of extra nutrient or drug for livestock which are harming dairy animals. with the increase in population, the demand for food material increased and the use of chemicals, fertilizers were continually used for more crop production.

Fertilizer application in India is large and the use of agrochemicals for greater crop production had ill effect on human health, environment and groundwater. The significant eco-accommodating advances deserving of referencing are organic farming, natural farming, traditional farming, sustainable farming, and permaculture, which may be all together considered as eco-friendly farming.

Ecological pesticides and green pesticides are those that are environmentally friendly, these pesticides do not harm environment, soil, water, animals and microorganism. In agriculture science, pesticides are evaluated for minimum environmental impact. An environmentally friendly agricultural technique, which does not harm nature, ensure food security, improve human health and plays an important role in conserving the environment.

Sustainable agricultural systems should be equitable in providing long-term food sufficiency, and social justice, and ecological sound for future generations and other species. The success of eco-friendly farm approach totally depends on awareness approach supported by the authentic source of input and knowledge from technical person. Therefore, it is essential to judge the depth of perception and adopt among the concerned farmers in relation to eco-friendly farming which is a prerequisite to developed a strategy for successful implementation of eco-friendly farming programme for a governmental organization particular farming community.
Therefore, a study was conducted with the following objectives for the study includes to study the profile of tribal farmers. And also to seek suggestive measure to minimize the ill effect of agrochemical as perceived by tribal farmers.

\section{Materials and Methods}

The present study was conducted in Sahapur and Bhimpur block of Betul district of M.P. From Betul district, Sahapur and Bhimpur Blocks were purposively selected based on tribal area of the district. The selected blocks comprise of 295 villages. A combined list of villages of both selected blocks where tribal farmers were engaged in agriculture was prepared with help of extension officials.

Out of these, 10 villages were selected randomly for the study. After the selection of the villages, a village wise list of tribal farmers was prepared and twelve tribal farmers were selected in each village by using simple random sampling method.

Thus, the total sample was consisted 120 respondents for the study. The data were collected personally with the help of a pretested interview schedule. The interview schedule was designed for collecting the relevant information of selected variables. All the respondents had answered the questions fully, which was indicative of the fact that good rapport could be established between the investigator and respondents.

After establishing rapport with the respondents, they were interviewed and their responses recorded in interview schedule, for analysis of data. Secondary data were collected from records \& statistical office. Statistical tools like- mean, SD, percentage and Karl Pearson's coefficient of correlation and multiple regression analysis [1-9]. 


\section{Results and Discussion}

The data in Table 1 shows that maximum number of the respondents $(48.33 \%)$ belonged to middle age group, followed by old age (20\%). Higher percentage of the respondents $(31.67 \%)$ were educated up to primary level followed by $(24.17 \%)$ middle school level, whereas, 12.50 per cent Illiterate, 20.83 per cent high school and 10.83 per cent of the respondents were above high school.

Majority of the respondents (44.16\%) belonged to medium size of family (5 to 8 members), followed by 34.16 per cent respondents had large size of family (>8 members). Out of the total 120 tribal farmers, 25.83 percent respondents had low social participation; followed by 40.84 per cent respondents had medium social participation.

41.67 per cent respondents were marginal farmers, followed by 27.5 per cent had small size of land holding, 15.83 per cent respondents were from medium category, and 15.00 per cent were in large category.

Majority 56.67 per cent respondents were having medium annual income while 25 per cent of the respondents had low level annual income and 18.33 per cent had high annual income

46.66 per cent respondents were in medium credit availability category, while 17.5 per cent of the respondents were high level credit availability. The data showed that 57.50 per cent of the respondents engaged in agriculture followed by 25.84 percent of the respondents engaged in agriculture and only 16.66 percent respondents engaged in agriculture+ business +service/other.

Higher percentage of respondents $(56.67 \%)$ was found in the medium Source of information category followed by 19.17 per cent in the low category. It is apparent from the Table 1 that majority $(49.17 \%)$ of the tribal farmers possessed medium level of material possession, while 26.67 per cent possessed low medium level of material possession.

It is evident from the Table 1 that the majority 55.00 percent of respondents were from medium category of extension contact, while 18.34 percent of respondents were in low category of extension contact. It shows that out of total 120 respondent maximum $47.5 \%$ respondent were found to be in the medium extension participation category, while 23.33 $\%$ respondent were in the high extension participation category.

Majority of the respondents 40.83 per cent were in medium innovativeness category followed by 26.67 per cent in low category and only 32.5 per cent in high category of Innovativeness. As regard to the knowledge of eco-friendly practices, majority $(66.67 \%)$ of the respondents had medium, 21.66 per cent high and 11.67 per cent low level of knowledge about eco-friendly practices.

Adequate knowledge of any improved practice is a pre-requisite for its adoption. Research studies established that knowledge of an innovation would lead to its eventual adoption. The result expressed by the respondents regarding knowledge about ecofriendly practices was medium.

Information regarding the different aspects of environmental hazards (ill-effects of chemicals like their effect on human health, toxicity to animals, hazards to environment, non-target organisms, resistance developed by pests etc.) and eco-friendly practices (Integrated Pest Management and Integrated Nutrient Management) were collected from good number of relevant literature, books and consulting experts. 
Table.1 Socio-economic profile of respondents

\begin{tabular}{|c|c|c|c|c|c|c|}
\hline SN & Traits & Category & Frequency & Percentage & Mean & SD \\
\hline \multirow[t]{3}{*}{1} & \multirow[t]{3}{*}{ Age } & Young age (Below 35 years) & 38 & 31.67 & & \\
\hline & & Middle age (35 to 50 years) & 58 & 48.33 & & \\
\hline & & Old age (Above 50 years) & 24 & 20 & & \\
\hline \multirow[t]{5}{*}{2} & \multirow[t]{5}{*}{ Education } & Illiterate & 15 & 12.5 & & \\
\hline & & Primary school & 38 & 31.67 & & \\
\hline & & Middle school & 29 & 24.17 & & \\
\hline & & High School & 25 & 20.83 & & \\
\hline & & Above high school & 13 & 10.83 & & \\
\hline \multirow[t]{3}{*}{3} & \multirow[t]{3}{*}{ Family Size } & Small ( $<5$ members $)$ & 26 & 21.67 & & \\
\hline & & Medium (5 to 8 members) & 53 & 44.16 & & \\
\hline & & Large (>8 members) & 41 & 34.17 & & \\
\hline \multirow[t]{3}{*}{4} & \multirow{3}{*}{$\begin{array}{c}\text { Social } \\
\text { Participation }\end{array}$} & Low (up to 4 score) & 31 & 25.83 & & \\
\hline & & Medium (5 to 9 score) & 49 & 40.84 & & \\
\hline & & High (Above 9 score) & 40 & 33.33 & & \\
\hline \multirow[t]{3}{*}{5} & \multirow{3}{*}{$\begin{array}{l}\text { Annual } \\
\text { Income }\end{array}$} & Low (Up to Rs 50,000/-) & 30 & 25 & & \\
\hline & & Medium (Rs. 50,001 to $1,00,000 /-$ ) & 68 & 56.67 & & \\
\hline & & High (Above Rs. 1,00,000) & 22 & 18.33 & & \\
\hline \multirow[t]{4}{*}{6} & \multirow[t]{4}{*}{ Land Holding } & Marginal farmers (< 1ha.) & 50 & 41.67 & & \\
\hline & & Small farmers (1-2ha.) & 33 & 27.5 & & \\
\hline & & Medium farmers (2.1- 5 ha.) & 19 & 15.83 & & \\
\hline & & Large farmers (> 5 ha.) & 18 & 15 & & \\
\hline \multirow[t]{3}{*}{7} & \multirow{3}{*}{$\begin{array}{c}\text { Credit } \\
\text { Availability }\end{array}$} & Poor credit availability & 43 & 35.84 & & \\
\hline & & Moderate credit availability & 56 & 46.66 & & \\
\hline & & Good credit availability & 21 & 17.5 & & \\
\hline \multirow[t]{3}{*}{8} & \multirow[t]{3}{*}{ Occupation } & Agriculture (1score) & 31 & 25.84 & & \\
\hline & & Agriculture+ business (2 score) & 69 & 57.5 & & \\
\hline & & $\begin{array}{l}\text { Agriculture+ business } \\
\text { +service/other ( } 3 \text { score) }\end{array}$ & 20 & 16.66 & & \\
\hline \multirow[t]{3}{*}{9} & \multirow{3}{*}{$\begin{array}{l}\text { Source of } \\
\text { Information }\end{array}$} & Low $(<1.4$ score $)$ & 23 & 19.17 & \multirow[t]{3}{*}{2.10} & \multirow[t]{3}{*}{0.7} \\
\hline & & Medium (between 1.4 to 2.8 ) & 68 & 56.67 & & \\
\hline & & High $(>2.8)$ & 29 & 24.16 & & \\
\hline \multirow[t]{3}{*}{10} & \multirow{3}{*}{$\begin{array}{l}\text { Material } \\
\text { Possession }\end{array}$} & Low (<1.26 score) & 32 & 26.67 & \multirow[t]{3}{*}{1.98} & \multirow[t]{3}{*}{0.72} \\
\hline & & Medium (between 1.26 to 2.70 ) & 59 & 49.17 & & \\
\hline & & High $(>2.70)$ & 29 & 24.16 & & \\
\hline \multirow[t]{3}{*}{11} & \multirow{3}{*}{$\begin{array}{l}\text { Extension } \\
\text { Contact }\end{array}$} & Low (below 3 times in a season) & 22 & 18.34 & & \\
\hline & & Medium ( 3 to 6 times in a season) & 66 & 55 & & \\
\hline & & High (above 6 times in a season) & 32 & 26.66 & & \\
\hline
\end{tabular}




\begin{tabular}{|c|c|c|c|c|c|c|}
\hline \multirow[t]{3}{*}{12} & \multirow{3}{*}{$\begin{array}{c}\text { Extension } \\
\text { Participation }\end{array}$} & Low Extension participation & 35 & 29.17 & & \\
\hline & & Medium Extension participation & 57 & 47.5 & & \\
\hline & & High Extension participation & 28 & 23.33 & & \\
\hline \multirow[t]{3}{*}{13} & \multirow[t]{3}{*}{ Innovativeness } & Low $(<1.288$ score $)$ & 32 & 26.67 & \multirow[t]{3}{*}{2.06} & \multirow[t]{3}{*}{0.77} \\
\hline & & Medium (between 1.288 to2.828) & 49 & 40.83 & & \\
\hline & & $\operatorname{High}(>2.828)$ & 39 & 32.5 & & \\
\hline \multirow[t]{3}{*}{14} & \multirow{3}{*}{$\begin{array}{l}\text { Distribution of } \\
\text { respondents } \\
\text { according to } \\
\text { their } \\
\text { knowledge }\end{array}$} & Low $(<23.064)$ & 14 & 11.67 & \multirow[t]{3}{*}{26.00} & \multirow[t]{3}{*}{2.936} \\
\hline & & Medium (23.064-28.936) & 80 & 66.67 & & \\
\hline & & High $(>28.936)$ & 26 & 21.66 & & \\
\hline
\end{tabular}

Table.2 Suggestive measure to minimise the ill effect of agrochemicals as perceived by farmers

\begin{tabular}{|c|l|c|c|}
\hline S. N. & Suggestions made & Frequency & Percent \\
\hline $\mathbf{1}$ & Making available pest resistant varieties & 105 & 87.50 \\
\hline $\mathbf{2}$ & Organizing training on eco-friendly practices & 90 & 75.00 \\
\hline $\mathbf{3}$ & $\begin{array}{l}\text { Encouraging farmers to grow organic Agriculture crops } \\
\text { through subsidies, technical guidance etc. }\end{array}$ & 83 & 69.17 \\
\hline $\mathbf{4}$ & Ensure strict quality control measures for pesticides & 79 & 65.83 \\
\hline $\mathbf{5}$ & Use of bio-pesticides and bio-fertilizers must be increases & 65 & 54.17 \\
\hline $\mathbf{6}$ & Use of bio-control agents in control of pests must be & 59 & 49.17 \\
\hline $\mathbf{7}$ & increased & & \\
\hline $\mathbf{8}$ & Give premium price for organically growing Agriculture & 42 & 35.00 \\
\hline $\mathbf{9}$ & Educate public and farmers about the environmental issues & 56 & 46.67 \\
\hline $\mathbf{1 0}$ & Introducing environmental education at the secondary level & 38 & 29.17 \\
\hline & & 31.67 \\
\hline
\end{tabular}

Measures to minimize the ill effects of agrochemicals

The results in Table 2 indicated that the majority of the respondents suggested making availability of pest resistant varieties $(87.50 \%)$, followed by three-fourth of respondents said organizing training on ecofriendly practices $(75.00 \%)$.

The results in Table 2 indicated that the majority of the respondents suggested making availability of pest resistant varieties $(87.50 \%)$, followed by three-fourth of respondents said organizing training on ecofriendly practices $(75.00 \%)$. Nearly two-third of respondents suggested encouraging farmers to grow organic Agriculture through subsides, technical support etc. (69.17\%) and ensure quality control measures for pesticides $(65.83 \%)$. Use of bio-pesticides and biofertilizers must be increased was suggested by 54.17 per cent of the respondents.

Nearly fifty per cent of the respondents suggested about use of bio-control agents in control of pest must be increased $(49.17 \%)$ and educating public and farmers about environmental issues (46.67\%). Thirty-five per cent farmers suggested about giving premium price for organically grown agriculture. Introduction of environmental education at secondary level and establishing a network of farmers adopting organic farming was suggested by 31.67 per cent and 29.17 per cent, respectively. 
The study revealed that variables like education, social participation, size of land holding, annual income, credit availability, occupation, source of information, material possession, extension contact, extension participation and innovativeness were positively and significantly correlated with knowledge about eco-friendly practices at 1 percent level of significance and education, social participation, credit availability, extension participation, extension contact and innovativeness were positively and significantly correlated with adoption of ecofriendly practices at 1 percent level of significance.

\section{References}

Agriculture-Man-Ecology (1991). Sustainable agriculture-intensive research will play off. The Hindu, Survey of Indian Agriculture, pp. 17-20.

Agriculture-Man-Ecology (1992). Ecological Agriculture in South India, Agricultural Economics Research Institute. The Hauge, Netherlands, pp. 70.

Badodiya S.K.; Daipuria O. P.; Jaulkar A. M. and U. Dhakad (2010) Management of eco-friendly practices by winter vegetable growers. Paper presented in National Seminar on Organic Farming \& Published
Gour et al., (2014) Knowledge of winter vegetable growers about eco-friendly practices, SKUAST Journal of Agriculture Research, 16: 105-112.

Mandavi Mishra, Role of Eco-Friendly Agricultural Practices in Indian Agriculture Development, International Journal of Agriculture and Food Science Technology (IJAFST) ISSN No. 2249-3050, Volume 4 No. 2 (2013)

Neerja Patel, Sandhya Choudhary, \&Dr. V. K. Swarnakar Study on Adoption of EcoFriendly Management Practices by Vegetable Growers in Indore Block of Indore District (M.P.) IOSR Journal of Agriculture and Veterinary Science

Rane Satish, (2016) "A Study on Adoption of Eco-friendly Farming Practices Among Rice Grower of Hanumana Block of Reva District (M.P), Unpublished M.Sc. (Ag) Thesis, collage of Agriculture JNKVVJabalpur (M.P)

S. Srisruthi, N. Swarna, G. M. S. Ros and E. Elizabeth, "Sustainable agriculture using eco-friendly and energy efficient sensor technology," 2016 IEEE International Conference on Recent Trends in Electronics, Information \& Communication Technology (RTEICT), Bangalore, 2016, pp. 14421446.

\section{How to cite this article:}

Bihare, G., P. Kumar, Singhshivpal, G. Uikey and Badodiya, S. K. 2020. A Critical Comprehension of Carbon Neutral Management Practices in Agriculture by Tribal Farmers of Betul District of M.P, India. Int.J.Curr.Microbiol.App.Sci. 9(05): 2032-2037. doi: https://doi.org/10.20546/ijcmas.2020.905.231 